\title{
The Albanian-Greek Relations Following the Sea Border Issue
}

\author{
Dorina Ndoj \\ PhD Candidate \& Lecturer \\ European University of Tirana \\ dndoj1@uet.edu.al
}

\begin{abstract}
The paper seeks to explore the Albanian-Greek relations following the sea border dispute analyzing Albanian political elite's discourse. Throughout the history various and complex issues have determined the relations between Greece and Albania, which sometimes have caused tension and disputes between them. The two countries have been on a dispute on the sea border issue because the Albanian Constitutional Court nullified the 2009 mutual agreement signed by previous Albanian and Greek governments due to territorial integrity violations. More than five years later the two countries have not settled the maritime borders yet. This study concentrates on depicting the relations between two countries after this episode happened. It question: how this issue affected the relations among two countries? The main claim of this article is that a new issue of concern is detected in the bilateral relations, such as exclusive economic zones issue. The exploration of economic exploitation zones in the lonian Sea urges for the delimitation of maritime borders between two countries, and therefore the renegotiation of "sea agreement" is inevitable in near future. Methodology used to conduct the analysis is discourse analysis.
\end{abstract}

Keywords: Albanian-Greek Relations, Sea Border Dispute, Political Elite's Discourse, Discourse Analysis.

\section{Introduction}

Bilateral relations with Greece represent an important aspect of Albania's foreign policy. Greece is a neighbor country as well as a strategic partner of Albania. Throughout the history various and complex issues have determined the relations between Albania and Greece, which sometimes have caused tension and disputes among two countries. Despite the mutually declarations to develop close and friendly relations among them, the diplomatic relations have been marked by conflict and different approaches on some relevant bilateral issues. The most important issues that continuously raise concerns between two countries have been the Law of War, the Cham issue, Albanian migrants in Greece, Greek minority in Albania, and more recently the maritime borders.

Since April 2010 the two countries have been on a dispute for not reaching a mutual deal on the sea border issue. On April 27, 2009, Albanian and Greek governments signed the 'Agreement for the Delimitation of the Albanian-Greek Continental Shelf and Maritime Zones', known for the public as 'Sea Agreement'. One year later the Albanian Constitutional Court nullified the agreement due to territorial integrity violations. The agreement was reached after less than two years of very confidential negotiations among governments of the two countries. The singing of the agreement was followed by unprecedented public objection by Albanian experts, academicians and opposite political parties who claimed that the agreement has caused substantial violations of Albanian border. Regarding the short time and very confidential negotiations as well as the content of the agreement, the negotiation team was faced with a public backlash, which claimed that negotiations have produced an irreconcilable deal with national interest of Albania. It was Socialist Party, former opposite party, which brought the agreement before the Constitutional Court. On April 15, 2010 the Albanian Constitutional Court nullified the agreement due to 'procedural and substantial violations of the Constitution and the UN Convention of the Law of the Sea'.

Given the fact that the delimitation of maritime borders has not been settled yet and 'sea agreement' is still an issue of concern between political elites of two countries, is valuable to investigate the construction of meaning attached to this issue in political discourse. The purpose of this study is to shed light on the Albanian-Greek relations following the sea border dispute analyzing political elite's discourse. The main questions are: how this event/episode affected the relations among two countries? In a broader context this study concentrates on depicting the relations between two countries after 
this episode happened. The main claim of this article is that a new issue of concern is detected in the bilateral relations, such as exclusive economic zones issue. The exploration of economic exploitation zones in the lonian Sea urges for the delimitation of maritime borders between two countries, and therefore the renegotiation of "sea agreement" is inevitable in near future.

\section{METHODOLOGY AND THEORETICAL FRAMEWORK}

Methodology used to conduct the study is discourse analysis. To investigate the evolution of the political elite's main arguments and positions on the sea agreement, I rely on discourse analysis. Foreign policy has generally been out of the object of study of discursive approaches due to its focus on ground theories of International Relations and hence [that is why] the discourse was not considered as an important tool of analysis. But in the last decades there has been an increase of studies that connect foreign policy with discourse analysis and they are becoming part of research agendas of many theoretical approaches such as the constructivism, post-structuralism and the critical theory.

The theoretical framework of this paper is based on the constructivist approach of Foreign Policy Analysis, combined with Critical Discourse Analysis. More specifically the European branch of constructivism is often prescribed as post-positivist or interpretative and that considers language to be a structure of meaning that makes possible specific actions of foreign policy. The interpretative constructivists analyze the historical conditions and social discourses that make possible the change in "the foreign policy behavior" (Hopf, 2002). The scholar Demirtas Bagdonas notes that "policy makers articulate their policies (present certain policies as a part of a general policy orientation or articulate the need to move away from traditional policy), and as such discourse analysis is the best mean to study the ideological templates constructed in foreign policy discourses" (2008: 52).

This study applies a discursive approach. Studies based on discourse analysis use language as an instrument that methodologically involves the process of reading and text interpretation of different speeches. Discourse analysis is based on the analysis of meanings of special concepts that structure and articulate what the actor is saying. According to Titscher et al. (2000:32) one of functions of texts is representation, through which we achieve to distinguish group or situational features that is object to analysis. The methodology applied for this article is Critical Discourse analysis, based on works of N. Fairclough, R. Wodak and T. Van Djik. Based on Weaver's idea (2004: 198) on discursive approaches, this article treats CDA both as a methodology and as a theoretical approach. By analyzing "discourse/ language as a social practice" (Faircluogh \& Wodak, 1997), it can facilitate the understanding of main themes/ issues of political discourse regarding the relation between two countries. Specifically CDA "is focused in the ways how discourse preserves, confirms, legitimates, reproduce and challenges power and dominance in society" (Van Dijk, 1988:953), and it also stresses out "how power relation are exercised and negotiated in discourse" (Wodak, 1996). According to Fairclough power within the discourse has to do with the dominant signifiers, who control and oblige the contribution of less powerful signifiers (Fairclough 1989: 46).

This article analyzes a group of texts, mainly declarations and speeches of high representatives of state and government of both Albania and Greece. This corpus of materials includes declarations held by state representatives in official bilateral meetings, agreements or any public appearances. Hence, a certain question emerges: Why we should focus on political elite's discourse? As many other political situations or actions, a major part of diplomatic activities happens in a discursive level and a detailed analysis of these practices does not only help to understand these practices but also explore the possible consequences in foreign policy. The study covers the period 2010 [after the nullification of agreement by Albanian Constitutional Court]-2015.

\section{DATA ANALYSIS \& FINDINGS}

More than five years later the issue is still pending and continuously brought up in bilateral meetings of high representatives of both governments. While two countries depict each other as friend, neighbor, strategic, partner, ally, ect., they have been sending different signals on the agreement. Based on a survey conducted by AllS on Albanian-Greek perceptions "almost half of Albanians mention that the priority number one issue if that of borders, with 49 percent of the answers" (Cela \& Lleshaj, 2013:22). This result makes sense referring the powerful media resonance that 'sea agreement' has gained over 
the years. The extent and intensity of media coverage on this issue has depended widely on the effect it provoked in the public opinion about potential consequences if the agreement shall be ratified. The picture emerged from media coverage has a strong negative portrait of 'sea agreement' assignment by the Albanian government. The headlines referred to agreement have depicted its negotiation on behalf of Albanian government as "sea was donated", "Albania gave sea away to Greece", and "sea was sold to Greece". The above 'negative' picture immediately raised concerns and called the policy makers out for renegotiation of agreement.

After the agreement was nullified by the Albanian Constitutional Court, Albania and Greece experienced another 'frozen" phase in the diplomatic relations among them. The Greek government reacted immediately rejecting the decision and therefore increasing the pressure on Albanian government for future ratification of agreement. In this context, a discourse of hostility between Albania and Greece has been constructed. While Albanian political elites aim to renegotiate the sea water agreement, Greek political elites have been steadily demanding for the implementation [ratification] of it despite the court decision. To put in Wodak's words, this is the case of "exercising power relation through discourse" (1996), were the Greek government as a 'dominant signifiers' (Fairclough, 1989) pressure the "less powerful signifiers" [Albanian government]. The dominant discourse of Greek political elites was that Albania would be unable to [obtain candidate status] start accession negotiations with the European Union without ratifying the agreement. Greece steadily has been using the "carrot and stick" methods as means of pressuring Albania regarding bilateral issues, by imposing itself as an important actor in relation to Albania's EU integration. On the July 15 the Greek Foreign Minister, Nikos Kotzias, has visited Tirana. Avoiding the discussion of sea agreement's issue, he noted that "Albania is a strategic partner, a strategic country and neighbor. God has sent us to live together in this area... we want to be as much as possible creative in preparing Albania's EU integration. I am very persistent towards international projects because everything that happens in the Balkans should include Albania. We have a policy of integration and not leaving out..." (Kotzias, 15 July 2015).

The dynamic within the Albanian political elite's discourse have been more nuanced and complex regarding the issue. It was the Socialist Party itself who brought it before court. "We should put an end this state of limbo, with conflict potential" expressed Rama, the head of the Socialist Party, in his request to the government of that time for the renegotiation of the maritime border agreement with Greece. After the Socialist Party came in power, in August 2014, Albanian foreign minister, Ditmir Bushati, asked the state prosecutor to launch an investigation against high officials involved in negotiations and signing the sea border agreement. In despite of that Albanian government emphasize the need to renegotiate the agreement it is mixed with incoherent statements. It is unclear if the there is any renegotiation of the maritime border yet, on what conditions, because high officials have made contradictory statements. Given the fact that Greece refused to renegotiate the terms of an agreement, lately the high officials of both governments have articulated the option of addressing the dispute to an international tribunal. But, both countries have knowledge that for the moment is not profitable for none of the states.

While the maritime borders have been at the centre of the dispute between two countries, another important issue has emerged. The debate over the sea border issue and maritime zones unfold another important issue between two countries such as potential oil exploration in the waters of the lonian. The unsuccessfully efforts for delimitation of the continental shelf and other maritime zones were followed by another disagreement between two countries about economic exploitation zones in the lonian Sea. After the Greek side has started search for oil in the lonian Sea, the Albanian media published a map claiming that it was published by the ministry of Energy of Greece, which suggested tenders for oil exploration even in the areas for which the agreement between Albania and Greece on the sea border was annulled. In the following days the Albanian Ministry of Foreign Affairs handed over a protest note to Athens, due to the lack of transparency for the maps and oil researches in the disputed area. This represents another issue of concern between two countries, which reveals the need for a new maritime border deal.

\section{CONCLUSIONS}

The overall of relations between Albania and Greece has been problematic. Since April 2010 the two countries have been on a dispute for not reaching a mutual deal on the sea border issue. More than five years later the issue is still pending and continuously brought up in bilateral meetings of high representatives of both governments. After the nullification of the "sea agreement" by the Albanian Constitutional Court, Greece have refused to accept the court decision and therefore refused to renegotiate the terms of an agreement. Greece steadily has been using the "carrot and stick" methods as means of 
pressuring Albania regarding the border issue, by imposing itself as an important actor in relation to Albania's EU integration. Given the fact that Greece refused to renegotiate the terms of an agreement, lately the high officials of both governments have articulated the option of addressing the dispute to an international tribunal, although both countries have knowledge that for the moment is not profitable for none of the states. The unsuccessfully efforts for delimitation of the continental shelf and other maritime zones were followed by another disagreement between two countries about economic exploitation zones in the lonian Sea. The main claim of this article is that a new issue of concern is detected in bilateral relations, such as exclusive economic zones issue. The exploration of economic exploitation zones in the lonian Sea urges for the delimitation of maritime borders between two countries, and therefore the renegotiation of "sea agreement" is inevitable in near future.

\section{REFERENCES}

[2] Bushati, D. (15 Korrik 2015). Bushati: Nese s'ka consensus per "Detin", e zgjidhim ne rruge nderkombetare. Gazeta Panorama.

[3] Fairclough, N. (1992). Discourse and Social Change. Cambridge: Polity Press.

[4] Kotzias, N, (15 Korrik 2015). Ministri grek: Nuk kemi ligj lufte me Shqipërinë. Gazeta Panorama.

[5] Larsen, H. (1997) Foreign Policy and Discourse Analysis: France, Britain and Europe. London: London School of Economics and Political Science / Routledge.

[6] Larsen, H. (1999) 'British and Danish European policies in the 1990's: A discourse approach' European Journal of International Relations Vol. 5(4): 451-483.

[7] Panarit, E. (27 Gusht 2012). Pakti detar, Panariti: S'ka negociata me Greqinë. Gazeta Panorama.

[8] Rama, E. (8 gusht 2013) Pakti detar, Rama: Zgjidhje me Greqinë. Gazeta Panorama.

[9] Titscher, S. et al (2000). Methods of Text and Discourse Analysis. London: Sage.

[10] Wæver, O. (2002). "Identity, communities and foreign policy: discourse analysis as foreign policy theory" in Lene Hansen and Ole Wæver (eds). European Integration and National Identity. The challenge of the Nordic States. London and New York: Routledge. 